\title{
ANALISIS YURIDIS RANGKAP JABATAN YANG DILAKUKAN OLEH NOTARIS SEBAGAI PEMIMPIN BADAN USAHA SWASTA (STUDI PUTUSAN MPP NOMOR:06/B/MPPN/X/2018)
}

\author{
ARTHA ULLY TAMBUNAN \\ Program Studi Magister Kenotariatan \\ Fakultas Hukum Universitas Sumatera Utara \\ Jalan Dr.T. Mansur Nomor 9, Kampus Padang Bulan, Medan \\ Telp. (061) 8211633, E-mail: arthatambunan46@gmail.com
}

\begin{abstract}
$\underline{\text { ABSTRACT }}$
Prohibition of two positions by a Notary as the head of a private company is regulated in Article 17, letter (f), but by the Decree of MPP (Central Supervisory Council) No. $06 / B / M P P N / X / 2018$, it is found that, in practice, there is still a contradiction between rules and reality in the field, especially the violation is done by a Notary who is the Vice Head of the Regional Honorary Ciuncil of Lampung Province. The research problems were as follows: why a Notary is prohibition to have two positions as the head of private company according to UUJN, how about the efforts of MPN to do supervision on Notary's two positions, and how about juridicial analysis on the Decree of MPP No. 06/B/MPPN/X/2018. The research used the theory of legal certainty, the theory of liability, and the theoy of authority. The research used juridicial normative method with descriptive analytic approach, the data consisted of primary data and secondary data which were obtained from the Office of the Ministry of Law and Human Rights, library research, and interviews with some informants.The result of the research shows that concerning the Decree of MPP No. $06 / B / M P P N / X / 2018 i n$ the level of its supervision there is a significant difference in the decrees of MPD, MPW, and MPP on their considerations to make decisions; they constitute the background of inaccurate examination done by the MPN (Notary Supervisory Council).
\end{abstract}

Keywords: Double, Position, Notary

\section{Intisari}

Larangan rangkap jabatan Notaris sebagai pemimpin badan usaha swasta diatur dalam Pasal 17 huruf (f), namun demikian dengan adanya Putusan MPP Nomor 06/MPPN/B/X/2018 membuktikan bahwa dalam praktiknya masih ditemukan pertentangan antara aturan dengan kenyataan di lapangan terlebih lagi Notaris yang melakukan pelanggaran merupakan Wakil Ketua Majelis Kehormatan Wilayah Provinsi Lampung. Oleh karena itu tesis ini akan membahas tentang mengapa Notaris dilarang melakukan rangkap jabatan sebagai pemimpin badan usaha swasta menurut UUJN, bagaimana upaya MPN dalam menjalankan fungsi pengawasan terhadap pelanggaran rangkap jabatan yang dilakukan oleh Notaris dan bagaimana analisis hukum Putusan Majelis Pengawas Pusat Nomor 06/B/MPPN/2018. Tesis ini menggunakan teori kepastian hukum, teori tanggungjawab dan teori kewenangan. Jenis penelitian yang digunakan adalah penelitian yuridis normatif yang bersifat deskriftif analitis. Data yang digunakan untuk menjawab penelitian ini adalah data primer dan data sekunder yang diperoleh dari penelitian di Kantor Kementrian Hak Asasi Manusia dan dari penelitian kepustakaan serta wawancara informan. Hasil penelitian ditemukan bahwa terhadap Putusan Majelis Pengawas Pusat Nomor 06/B/MPPN/2018 dalam tingkatan pemeriksaannya ada perbedaan putusan yang sangat timpang dari MPD, MPW dan MPP dikarenakan perbedaan 
pertimbangan-pertimbangannya dalam memutus. Perbedaan pertimbangan ini dilatarbelakangi dengan tidak detailnya pemeriksaan yang dilakukan Majelis Pengawas Notaris.

Kata kunci: Rangkap, Jabatan, Notaris

\section{A. Latar Belakang}

Keberadaan Notaris merupakan pelaksanaan dari hukum pembuktian melalui akta yang dibuatnya Notaris harus dapat memberikan kepastian hukum kepada masyarakat pengguna jasa Notaris. ${ }^{1}$ Sehingga dalam melaksanakan jabatannya Notaris harus berada dalam posisi netral agar dalam menjalankan jabatannya tidak ada keberpihakan oleh Notaris.

Notaris dilarang melakukan rangkap jabatan merupakan salah satu aturan larangan bagi Notaris baik yang terdapat dalam Undang-Undang Nomor 2 Tahun 2014 tentang Perubahan Atas UndangUndang Nomor 30 Tahun 2004 tentang Jabatan Notaris (selanjutnya disebut UUJN). Pasal 17 Notaris dilarang:

a. menjalankan jabatan di luar wilayah jabatannya;

b. meninggalkan wilayah jabatannya lebih dari 7 (tujuh) hari kerja berturut-turut tanpa alasan yang sah;

c. merangkap sebagai pegawai negeri;

\footnotetext{
${ }^{1}$ Herlien Budiono, Kumpulan Tulisan Hukum Perdata di Bidang Kenotariatan Buku Kedua, Citra Aditya Bakti, Bandung, 2013, h. 220.
}

d. merangkap jabatan sebagai pejabat negara;

e. merangkap jabatan sebagai advokat;

f. merangkap jabatan sebagai Pemimpin atau pegawai Badan Usaha Milik Negara, Badan usaha Milik Daerah atau Badan usaha Swasta;

g. merangkap jabatan sebagai Pejabat Pembuat Akta Tanah diluar wilayah jabatan Notaris;

h. menjadi Notaris Pengganti;

i. Melakukan pekerjaan lain yang bertentangan dengan norma agama, kesusilaan, atau kepatutan yang dapat mempengaruhi kehormatan dan martabat jabatan Notaris;

Kenyataannya dalam praktik, seiring waktu dengan kian bertambahnya jumlah orang yang menjalani profesi Notaris dari waktu kewaktu, ditambah dengan perkembangan teknologi dan adanya kesempatan bagi sebagian Notaris untuk mendapatkan klien sebanyak mungkin, namun ada pula Notaris yang susah dalam mendapatan klien. Hal ini membuat sebagian oknum Notaris sampai melakukan rangkap jabatan. 
Terdapat berbagai kasus Notaris yang melakukan pelanggaran, salah satu kasus pelanggaran rangkap jabatan dalam wilayah Kementerian Hukum dan Hak Asasi Manusia Sumatera Utara dalam hal ini Majelis Pengawas Notaris Wilayah Sumatera Utara sendiri terdapat satu kasus Notaris yang melakukan rangkap jabatan yang pada saat penulis melakukan penelitian tidak dapat dianalisis karena belum sampai tahap keputusan mengenai sanksi yang akan diberikan, oleh karena itu tidak dapat diteliti mendalam.

Kasus mengenai rangkap jabatan Notaris yang melatar belakangi penelitian ini yakni yang dilakukan oleh Notaris Chairil Anom., SH yang merupakan Notaris Kota Bandar Lampung. Kasus ini bermula dengan adanya laporan yang dilakukan oleh Pengurus Pusat Serikat Pekerja Perkebunan Nusantara VII (selanjutnya disebut SPPN VII) kepada Majelis Pengawas Daerah Notaris Kota Bandar Lampung.

Dalam laporannya SPPN VII yang diwakili oleh kuasanya menyampaikan hal-hal yang dilanggar bagi seorang Notaris. Salah satunya merupakan larangan rangkap jabatan yang diduga dilakukan oleh Notaris Chairul Anom., SH. SPPN VII melalui kuasanya menduga adanya rangkap jabatan yang dilakukan oleh Notaris yang berakibat merugikan pihak SPPN VII.

\section{B. Rumusan Masalah}

Berdasarkan uraian latar belakang tersebut di atas dapat dirumuskan beberapa permasalahan sebagai berikut:

1. Mengapa Notaris dilarang melakukan rangkap jabatan sebagai pemimpin badan usaha swasta menurut UUJN ?

2. Bagaimana upaya MPN dalam menjalankan fungsi pengawasan terhadap pelanggaran rangkap jabatan oleh Notaris?

3. Bagaimana analisis hukum Putusan Majelis Pengawas Pusat Nomor 06/B/MPPN/2018?

\section{Metodologi}

Jenis penelitian yang digunakan dalam penelitian ini adalah penelitian yuridis normatif. Penelitian normatif tersebut mengacu kepada norma-norma hukum yang terdapat dalam peraturan perundang-undangan dan putusan-putusan pengadilan serta norma-norma hukum yang ada dalam masyarakat.selain itu, dengan melihat sinkronisasi suatu aturan dengan aturan lainnya secara hierarki. ${ }^{2}$ Sumber data yang digunakan dalam penelitian ini bersumber dari data primer dan data sekunder. Data primer didapatkan melalui kegiatan penelitian lapangan yaitu

${ }^{2}$ Zainuddin Ali, Metode Penelitian Hukum, Raja Grafindo Persada, Jakarta, 1997, h. 38-39. 
berupa observasi dan wawancara terkait dengan permasalahan penelitian terhadap pelanggaran rangkap jabatan yang dilakukan Notaris sebagai Pemimpin badan Usaha Swasta, sehingga untuk membantu melancarkan penelitian ini dibutuhkan pendukung yaitu informan. Sedangkan data sekunder atau data kepustakaan yang terdiri dari bahan-bahan hukum. Bahan-bahan hukum tersebut terdiri dari bahan hukum primer yaitu peraturan perundang-undangan, yurisprudensi, traktat atau konvensi yang sudah diratifikasi, dan perjanjianperjanjian keperdataan para pihak; bahan hukum sekunder yaitu bahan yang memberikan penjelasan mengenai bahan hukum primer; dan bahan hukum tersier yaitu bahan yang memberikan petunjuk maupun penjelasan terhadap bahan hukum primer dan sekunder. ${ }^{3}$

Analisis data dalam penelitian ini menggunakan metode penelitian analisis data kualitatif. Metode analisis data kualitatif adalah analisis data yang tidak mempergunakan angka-angka tetapi berdasarkan atas peraturan perundangundangan, pandangan-pandangan informan sehingga dapat menjawab permasalahan dari peneltian ini. ${ }^{4}$ Setelah proses analisis

\footnotetext{
${ }^{3}$ Bahder Johan Nasution, Metode Penelitian Ilmu Hukum, Mandar Maju, Bandung, 2008, h. 86.

${ }^{4}$ Burhan Bungin, Analisis Data Penelitian Kualitatif, Pemahaman Filosofis Dan Metodologis
}

dilakukan, ditarik kesimpulan dengan menggunakan metode berpikir deduktif yaitu cara berpikir yang dimulai dari halhal yang umum untuk selanjutnya menarik hal-hal yang khusus.

D. PEMBAHASAN

I. Notaris Dilarang Melakukan Rangkap Jabatan Sebagai Pemimpin Badan Usaha Swasta Menurut UUJN

\section{a. Pengertian, Tugas dan Kewenangan Notaris}

Pengertian Notaris menurut Pasal 1 angka 1 UUJN menentukan "Notaris adalah pejabat umum yang berwenang untuk membuat akta autentik dan kewenangan lainnya sebagaimana dimaksud dalam undang-undang ini atau berdasarkan undang-undang lainnya". Sementara dalam penjelasan atas UUJN menyatakan bahwa : "Notaris adalah pejabat umum yang berwenang untuk membuat akta autentik sejauh pembuatan akta autentik tertentu tidak dikhususkan bagi pejabat umum lainnya".

Pengertian yang diberikan oleh UUJN tersebut merujuk pada tugas dan wewenang yang dijalankan Notaris. Artinya Notaris memiliki tugas sebagai pejabat umum dan memiliki wewenang

Kearah Penguasaan Modal Aplikasi, Raja Grafindo Persada, Jakarta, 2004, h. 53 
untuk membuat akta autentik serta kewenangan lainnya yang diatur oleh UUJN. ${ }^{5}$ Menurut Gandasubrata, Notaris adalah pejabat umum yang diangkat oleh pemerintah termasuk unsur penegak hukum yang memberikan pelayanan kepada masyarakat. ${ }^{6}$

Pasal 1 UUJN tidak memberikan uraian yang lengkap mengenai tugas Notaris. Menurut Lumban Tobing, bahwa selain untuk membuat akta-akta autentik, Notaris juga ditugaskan untuk melakukan pendaftaran dan mensahkan surat-surat atau akta-akta yang dibuat di bawah tangan. Notaris juga memberikan nasihat hukum dan penjelasan mengenai undangundang kepada pihak-pihak yang bersangkutan. Sedangkan menurut Setiawan, inti dari tugas Notaris selaku pejabat umum ialah mengatur secara tertulis dan autentik hubungan hukum antara pihak yang secara manfaat meminta jasa Notaris yang pada dasarnya adalah sama dengan tugas hakim yang memberikan keadilan diantara para pihak yang bersengketa.

Setiap perbuatan pemerintah disyaratkan harus bertumpu pada kewenangan yang sah. Tanpa ada

\footnotetext{
5 Abdul Ghofur Anshori, Lembaga Kenotariatan Indonesia Perspektif Hukum dan Etika, UII Press, Jakarta, 2009, h. 14.

6 H.R. Purwoto S. Gandasubrata, Renungan Hukum, IKAHI Cabang Mahkamah Agung RI, Jakarta, 1998, h. 484.
}

kewenangan yang sah seorang Pejabat ataupun Badan Tata Usaha Negara tidak dapat melaksanakan suatu perbuatan pemerintahan. Oleh karena itu kewenangan yang sah merupakan atribut bagi setiap Pejabat ataupun bagi setiap badan $^{7} \quad$ Kewenangan merupakan suatu tindakan hukum yang diatur dan diberikan kepada suatu jabatan berdasarkan peraturan perundang-undangan yang berlaku yang mengatur jabatan tersebut. Wewenang Notaris memiliki batasan sebagaimana diatur dalam perundangundangan yang mengatur jabatan pejabat yang bersangkutan.

Kewenangan Notaris dalam pembuatan akta, tecantum dalam ketentuan Pasal 15 UUJN, dimana kewenangan Notaris dibedakan menjadi 3 (tiga) macam, yaitu:

\section{Kewenangan Umum Notaris}

Kewenangan umum Notaris tercantum dalam Pasal 15 ayat (1) UUJN yang menegaskan bahwa salah satu kewenangan Notaris adalah membuat akta secara umum, namun dengan batasan sepanjang tidak dikecualikan kepada Pejabat lain yang ditetapkan oleh undang-undang, menyangkut akta yang harus dibuat atau berwenang membuat akta autentikmengenai semua perbuatan,

\footnotetext{
7 Lutfi Effendi, Pokok-Pokok Hukum Administrasi, Bayumedia Publishing, Malang, 2004, h. 77.
} 
perjanjian dan ketetapan yang diharuskan oleh aturan hukum atau dikehendaki oleh yang bersangkutan, mengenai subjek hukum (orang atau badan hukum) untuk kepentingan siapa akta dibuat atau dikehendaki oleh yang berkepentingan.

\section{Kewenangan Khusus Notaris}

Kewenangan khusus Notaris untuk melakukan tindakan hukum tertentu tercantum dalam Pasal 15 ayat (1) UUJN, seperti :

a. Mengesahkan tanda tangan dan menetapkan kepastian tanggal surat di bawah tangan dengan mendaftarkan ke dalam buku khusus;

b. Membukukan surat di bawah tangan dengan mendaftarkan ke dalam buku khusus;

c. Membuat copy dan asli surat di bawah tangan berupa salinan yang memuat uraian sebagaimana ditulis dan digambarkan ke dalam surat yang bersangkutan;

d. Melakukan pengesahan kecocokan fotocopy dengan surat aslinya;

e. Memberikan penyuluhan hukum sehubungan dengan pembuatan akta

f. Membuat akta yang berkaitan dengan pertanahan, atau membuat akta risalah lelang.

3. Kewenangan Notaris Yang Akan Ditentukan Kemudian
Wewenang Notaris yang akan ditentukan kemudian merupakan wewenang yang akan muncul akan ditentukan berdasarkan peraturan perundang-undangan. Dalam kaitan ini perlu diberikan batasan mengenai peraturan perundang-undangan yang dimaksud batasan perundang-undangan dapat dilihat dalam Pasal 1 angka 2 undang-Undang Nomor 5 Tahun 1986 tentang Peradilan Tata Usaha Negara, bahwa: Yang dimaksud dengan peraturan perundang-undangan dalam undang-undang ini ialah semua peraturan yang bersifat mengikat secara umum yang dikeluarkan oleh Dewan Perwakilan Rakyat bersama pemerintah baik ditingkat pusat maupun di tingkat daerah, serta semua keputusan badan atau pejabat tata usaha Negara, baik ditingkat pusat maupun ditingkat daerah, yang juga bersifat mengikat secara umum.

\section{b. Larangan Rangkap Jabatan Notaris}

Notaris selaku Pejabat umum diberikan kewenangan untuk membuat akta Autentik dan memiliki kewenangan lainnya sebagaimana dimaksud dalam UUJN atau berdasarkan peraturan perundang-undangan lainnya. ${ }^{8}$ Kewenangan Notaris dalam menjalankan

\footnotetext{
${ }^{8}$ Lihat Pasal 1 angka 1 UUJN.
} 
Jabatannya secara umum diatur dalam Pasal 15 UUJN UUJN.

Seorang Notaris Dalam waktu 60 (enam puluh) hari terhitung sejak pengambilan sumpah/janji jabatan Notaris, maka Notaris tersebut wajib menjalankan jabatan dengan nyata. ${ }^{9}$ Dalam menjalankan jabatan tersebut Notaris terikat dan wajib taat kepada Sumpah/janji jabatannya dimana salah satunya yang wajib ditaati dalam sumpah/janji sebelum menjalankan jabatannya adalah : "bahwa saya akan patuh dan setia kepada Negara Republik Indonesia, Pancasila dan Undang-Undang Dasar Negara Republik Indonesia Tahun 1945, Undang-Undang tentang Jabatan Notaris serta peraturan perundangundangan lainnya. ${ }^{10}$

Dalam UUJN disamping mengatur tentang kewajiban yang harus dijalankan atau harus ditaati juga mengatur tentang larangan-larangan ${ }^{11}$.

\section{c. Notaris Dilarang Melakukan Rangkap Jabatan Sebagai Pemimpin Badan Usaha Swasta Menurut UUJN}

Dalam UUJN tidak dijelaskan alasan mengapa Notaris dilarang merangkap jabatan sebagai Pemimpin atau pegawai Badan Usaha Milik Negara (BUMN) atau Badan Usaha Milik Daerah (BUMD) atau Badan Usaha Swasta. Jabatan Notaris adalah jabatan kepercayaan, Jabatan dimana semua pihak yang menggunakan jasa hukum kepada Notaris begitu yakin dan percaya bahwa para pihak yang berhubungan dengan Notaris akan diperlakukan adil dan seimbang, benarbenar bebas dari unsur-unsur profit.

Jabatan Notaris adalah Jabatan terhormat (Officium Nobile) karena Notaris selaku Pejabat Umum merupakan jabatan kepercayaan (Vertrouwens Ambt) dan secara personal Notaris adalah seorang yang dipercaya oleh masyarakat dalam pembuatan alat bukti berupa akta Autentik(Vertrouwens Person). Larangan rangkap jabatan Notaris sebagai pemimpin badan usaha berkaitan erat dengan bentuk spesialisasi yang mengharuskan seorang Notaris bersikap profesional dimana salah

${ }^{9}$ Lihat Pasal 7 ayat (1), huruf (a) UUJN.

${ }^{10}$ Lihat pasal 4 UUJN Tentang sumpah atau janji Notaris sebelum melaksanakan jabatnnya.

11 Dalam Kamus Besar Bahasa Indonesia, Edisi kedua, cetakan ke empat, Balai Pustaka, h.567. disebutkan bahwa larangan berasal dari kata larang atau melarang yang maknanya memerintahkan supaya tidak melakukan sesuatu atau tidak memperbolehkan berbuat sesuatu. satunya yaitu dengan berkonsentrasi pada satu profesi yang telah ia putuskan untuk ia jalani. Disamping itu larangan tersebut juga bertujuan untuk mencegah terjadinya 
benturan kepentingan (conflict of interest,) serta agar Notaris itu tetap independen dan netral.

\section{Upaya MPN Dalam Menjalankan Fungsi Pengawasan Terhadap Pelanggaran Rangkap Jabatan Oleh Notaris}

Pada dasarnya, segala bentuk pengawasan dan lembaga pengawasan terhadap profesi Notaris muncul karena adanya kebutuhan akan penegakan etika profesi itu sendiri, dimana etika profesi tersebut berisi tentang nilai-nilai baik dan buruk, yang boleh dan tidak boleh dilakukan, dan mengenai kepatutan berkaitan dengan pelaksanaan profesi Notaris. Sanksi etika dapat diekspresikan secara terlembagakan dalam bentuk teguran, peringatan atau dalam kaitannya dengan status keanggotaan dalam suatu kelembagaan organisasi yakni pemberhentian keanggotaan dalam suatu kelembagaan organisasi yakni pemberhentian keanggotaan, baik secara tetap atau sementara waktu (skorsing). ${ }^{12}$

Pelaksanaan profesi Notaris dipandang sebagai sikap hidup, yang berupa kesediaan untuk memberikan pelayanan profesional di bidang hukum

${ }^{12}$ Herlina Ernawati Napitupulu, Peran Ikatan Notaris Indonesia Dalam Pembinaan Notaris Dan Pengawasan Kode Etik Notaris di Wilayah Sumatera Utara, Tesis, Magister Kenotariatan Universitas Sumatera Utara, Medan, 2017, hal. 74. terhadap masyarakat dengan keterlibatan penuh dan keahlian dalam rangka melaksanakan tugas yang berupa kewajiban terhadap masyarakat yang membutuhkan pelayanan hukum dengan disertai refleksi yang seksama, dan oleh karena itu di dalam melaksanakan profesinya terdapat kaidah-kaidah pokok berupa kode etik profesi.

Di samping itu pengawasan dilaksanakan karena adanya kebutuhan untuk menjaga kepercayaan dari masyarakat terhadap profesi Notaris sebagai pengguna jasa. Untuk mencapai sebuah praktek pengawasan yang ideal, pada prinsipnya pengawasan sangat bergantung kepada bagaimana pengawasan itu dijalankan. Dengan kata lain, pelaksanaan pengawasan harus disesuaikan dengan kebutuhan dan tujuan yang hendak dicapai melalui pengawasan tersebut.

Adapun kelebihan dari pembentukan Majelis Pengawas Notaris yaitu ${ }^{13}$ :

a. Pada saat pengawasan berada di bawah Pengadilan Negeri, fungsi pengawasan tersebut bukanlah hal utama yang mendapat perhatian dari aparatur Pengadilan Negeri, hal tersebut oleh karena Pengadilan Negeri memang bukan dibentuk

13 Hasil wawancara dengan Bapak Winanto Wiryomartani, Wakil Ketua MPP Notaris S, pada tanggal 12 Maret 2019. 
untuk melakukan pengawasan nonjudisial tetapi lebih cenderung kepada praktek persidangan dan penyelesaian kasus di pengadilan. Dengan adanya Majelis Pengawas Notaris yang secara khusus dibentuk untuk melakukan pengawasan, maka pelaksanaan pengawasan tersebut dapat dilaksanakan lebih maksimal karena memang diperuntukkan untuk melakukan pengawasan.

b. Dengan adanya Majelis Pengawas Notaris pengawasan yang dilakukan dapat lebih terarah dan sistematis, Majelis Pengawas Notaris dapat membuat programprogram pengawasan secara sungguh-sungguh dan terus menerus sehingga memperoleh hasil yang optimal. Dengan adanya Majelis Pengawas Notaris, maka tujuan pengawasan akan lebih mudah direalisir.

Berdasarkan Peraturan Menteri pada Pasal 1 angka 5 pengawasan adalah kegiatan yang bersifat preventif dan kuratif termasuk kegiatan pembinaan yang dilakukan oleh Majelis Pengawas terhadap Notaris. Untuk melaksanakan kegiatan pengawasan tersebut Majelis Pengawas Daerah diberikan kewenangan seperti dinyatakan pada ketentuan Pasal 70 UUJN jo Pasal 13 dan Pasal 14 Peraturan Menteri, yang pelaksanaan tugasnya diatur pada Keputusan Menteri. Berdasarkan ketentuan-ketentuan di atas, penulis mencoba untuk mengidentifikasi kewenangan-kewenangan pengawasan yang bersifat preventif yang antara lain adalah : hal-hal yang diatur Pasal 70 huruf b, c, d, e, f dan h UUJN, Pasal 13 ayat 2 huruf $\mathrm{a}, \mathrm{b}, \mathrm{c}$, e dan $\mathrm{f}$, dimana kewenangankewenangan tersebut bersifat administratif yang lebih mengatur tentang cara prosedural dan protokol kenotariatan serta kewenangan-kewenangan pengawasan yang bersifat kuratif yang antara lain adalah : hal-hal yang diatur Pasal 70 huruf a dan huruf g UUJN, Pasal 13 ayat 2 huruf d yang mengatur tentang pengambilan tindakan terhadap dugaan-dugaan pelanggaran yang dilakukan oleh Notaris terhadap UUJN dan Kode Etik Natoris.

Langkah-langkah pencegahan dan pembinaan yang dapat dilakukan oleh Majelis Pengawas Notaris idealnya harus dapat meningkatkan mutu dan kualitas pelayanan Notaris. Pencegahan dan pembinaan yang dilakukan harus didasari oleh kesadaran dan pemahaman yang tinggi atas nilai-nilai moral dan etika, untuk itu perlu diawali dengan menyamakan pandangan terlebih dahulu antara pihak-pihak terkait sehingga dapat mencapai suatu visi dan misi yang sama 
baik dalam pola pikir dan dalam tingkat pelaksanaannya, dengan demikian diharapkan tindakan pencegahan dan pembinaan yang kemudian akan dijalankan dapat mencapai tujuannya.

Berkenaan dengan tujuan yang hendak dicapai dengan adanya Majelis Pengawas yaitu meningkatkan profesionalisme dan kualitas kerja Notaris, sehingga dapat memberikan jaminan kepastian dan perlindungan hukum bagi penerima jasa Notaris dan masyarakat luas, maka dapat dikatakan pengawasan yang bersifat preventif dan kuratif masih belum dapat menjangkau atau belum maksimal untuk mencapai tujuan tersebut di atas mengingat profesi Notaris sangat tertutup oleh karena kerahasiaan jabatan harus tetap dijaga. Misalnya terjadi praktek kenotariatan yang tidak jujur dalam hal wilayah kerja, apabila ada Notaris yang bekerja di luar wilayah kerjanya, sejauh mana MPD dapat mengetahui dan membuktikan hal tersebut dan sejauh mana majelis pengawas berani mengambil tindakan atas pelanggaran tersebut.

Upaya lain yang dilakukan oleh MPP dalam menyikapi kendala akibat tidak adanya standar prosedur operasional pengawasan Notaris adalah dengan mengirimkan formulir-formulir seperti: formulir cuti dan formulir pemeriksaan 1 (satu) kali dalam setahun, namun hal tersebut sifatnya hanya kebijakan dari MPP saja yang tidak diatur secara tegas dalam peraturan perundang-undangan yang ada. ${ }^{14}$

Pasal 85 UUJN hanya menyebutkan bahwa berkaitan dengan pelanggaran terhadap Pasal 17 maka dapat dikenai sanksi berupa:
a. teguran lisan
b. teguran tertulis
c. pemberhentian sementara
d. pemberhentian dengan hormat; atau
e. pemberhentian dengan tidak hormat.

Dalam Pasal 85 tersebut bahwa pelanggaran terhadap Pasal 17 dapat mengakibatkan seorang Notaris dikenai sanksi berupa teguran lisan, teguran tertulis, pemberhentian dengan hormat atau pemberhentian dengan tidak hormat.

\section{III.Analisis Hukum Putusan Majelis Pengawas Pusat Nomor 06/B/MPPN/2018}

Analisis Yuridis adalah menguraikan data dan fakta hukum (das sein) yang terjadi, lalu disesuaikan dengan ketentuan yang sebenarnya (das sollen). ${ }^{15}$

14 Hasil wawancara dengan Bapak Winanto Wiryomartani, Wakil Ketua MPP Notaris , pada tanggal 12 Maret 2019.

15 Andi Prastowo, Memahami Metode-Metode Penelitian Suatu Tinjauan Teoritis dan Praktis. Ruzz Media, yogyakarta, 2011, h. 118. 
Berdasarkan fakta dari kasus tersebut, analisis yang dapat dikemukakan adalah bahwa Terlapor dalam menjalankan jabatannya sebagai Notaris tidak mengemban jabatannya dengan profesional serta lalai mematuhi peraturan perundang-undangan dan Kode Etik Notaris. Dengan demikian, akibat hukumnya adalah pemberian sanksi. Dalam menjatuhkan sanksi Majelis Pengawas memberikan pertimbanganpertimbangan yang menjadi dasar dalam memutus suatu perkara.

Bahwa tindakan Terlapor dengan membuat Akta Penyimpanan Nomor 5 tertanggal 5 September 2005 yang berisi tentang pembagian lahan yang kemudian menjadi sengketa antara PTPN VII dan PT. Bumi Madu Mandiri yang pada saat bersamaan juga Terlapor menjabat selaku kuasa Direksi PT. Bumi Madu Mandiri berdasarkan Surat Kuasa Direksi Nomor 019/BMM-DIR/VII/2017 dan Nomor 023/DIRUT-BMM/X/2017, hal ini menunjukkan adanya keberpihakan Terlapor terhadap satu pihak sehingga mengancam pelaksanaan kewajiban Notaris yang diatur dalam Pasal 15 UUJN. Singkatnya dengan Surat Kuasa tersebut Terlapor melakukan segala sesuatu yang diperlukan demi tercapainya maksud pemberian kuasa tersebut.
Bahwa dalam surat kuasa yang dibuat tersebut pekerjaan Terlapor mencantumkan pekerjaan sebagai Jasa Hukum, hal ini menandakan seolah-olah Terlapor merupakan kuasa hukum dari PT. Bumi Madu Mandiri. Bahwa berdasarkan Akta Pernyataan Keputusan RUPSLB PT. Bumi Madu Mandiri Nomor 120 tertanggal 26 September 2015 yang dibuat dihadapan Asvi Maphilindo Volta, SH. Notaris Kota Bandar Lampung, telah didaftarkan dalam Data Base Direktorat Jenderal Administrasi Hukum Umum perihal pemberitahuan perubahan Data Perseroan PT. Bumi Madu Mandiri berdasarkan Surat Nomor AHU-AH.01.030968054 tertanggal 29 September 2015, dalam perubahan ke 12 (dua belas) tertera dalam pengurus dan pemegang saham tercantum nama Terlapor Jabatan Direktur.

Dengan demikian terbukti bahwa Terlapor Notaris Kota Bandar Lampung telah merangkap Jabatan yang dilarang dalam UUJN Pasal 17 ayat (l) huruf f dan i yang menyatakan bahwa Notaris dilarang merangkap jabatan sebagai pemimpin atau pegawai badan usaha milik negara, badan usaha milik daerah atau badan usaha swasta, serta dilarang melakukan pekerjaan lain yang bertentangan dengan norma agama, kesusilaan, atau kepatutan yang dapat memengaruhi kehormatan dan martabat jabatan Notaris. 
Bahwa berdasarkan keterangan Terlapor kepada MPP melalui surat panggilan Nomor: UM.MPPN.11.18-132 Terlapor tidak jujur dengan menyatakan mengambil cuti dan kemudian mengakui di ruang siding bahwa Terlapor pada waktu bersamaan menjabat sebagai Notaris menjabat pula sebagai Direksi PT. Bumi Madu Mandiri. Bahwa berdasarkan keputusan MPW Prov Lampung Terlapor mengajukan cuti selama 1 (satu) tahun tertanggal 29 Oktober 2014 yang terhitung mulai tanggal 1 November 2014 s/d 31 Oktober 2015 dan kemudian mengajukan cuti kembali tertanggal 30 Oktober 2015, terhitung 10 November 2015 s/d 10 Mei 2016.

Bahwa berdasarkan fakta Terlapor telah menjabat sebagai Direktur PT. Bumi Madu Mandiri sejak 26 September 2015 s/d 24 Juni 2016 dan mengajukan cuti sejak 1 November 2014 s/d 31 Oktober 2015 dan 10 November 2015 s/d 10 Mei 2016.
Sehingga ada jeda waktu pada tanggal 26 September 2015 s/d 9 November 2015 dan 11 Mei 2016 s/d 24 Juni 2016, Terlapor merangkap jabatan sebagai pemimpin atau pegawai badan usaha swasta. Dengan demikian sesuai dengan Pasal 17 ayat (2) UUJN Notaris yang melanggar ketentuan sebagaimana dimaksud dalam ayat (1) dapat dikenai sanksi berupa:

a. Peringatan tertulis;

b. Pemberhentian sementara;

c. Pemberhentian dengan hormat;

d. Pemberhentian dengan tidak hormat.

Bahwa berdasarkan Pasal 3 ayat (2) dan ayat (3) jo. Pasal 10 Peraturan Menteri Hukum dan Hak Asasi Manusia Nomor 61 Tahun 2016 Tentang Tata Cara Penjatuhan Sanksi Administratif Terhadap Notaris, menyatakan bahwa Penjatuhan sanksi administratif dilakukan secara berjenjang mulai dari sanksi teringan sampai sanksi terberat sesuai dengan tata urutan sebagaimana dimaksud pada ayat (1).

\begin{tabular}{|c|l|}
\hline 29 Oktober 2014 & Terlapor mengajukan cuti selama 1 tahun pada MPW Prov Lampung \\
\hline 01 November 2014 & Terlapor cuti selama 1 tahun \\
31 Oktober 2015 & \\
\hline 30 Oktober 2015 & $\begin{array}{l}\text { Terlapor kembali mengajukan cuti selama } 6 \text { bulan pada MPW Prov } \\
\text { Lampung }\end{array}$ \\
\hline s/d & Terlapor cuti selama 6 bulan \\
$10 \mathrm{Mei} 2016$ & \\
\hline
\end{tabular}




\begin{tabular}{|c|c|}
\hline 26 September 2015 & $\begin{array}{l}\text { Dibuat akta pernyataan Terlapor sebagai direktur berdasarkan } \\
\text { keputusan RUPSLB PT. Bumi Madu Mandiri Nomor: } 120 \text { dihadapan } \\
\text { Asvi Maphilindo Volta, SH Notaris Kota Bandar Lampung }\end{array}$ \\
\hline 24 Juni 2016 & $\begin{array}{l}\text { Akta pernyataan kemudian diubah dengan akta nomor: } 36 \text { dihadapan } \\
\text { Budi Nugroho, SH Notaris Kabupaten Lampung Tengah yang } \\
\text { tercantum dalam database Ditjen AHU perubahan ke } 13 \\
\text { pemberitahuan perubahan data perseroan. }\end{array}$ \\
\hline $\begin{array}{l}26 \text { September } 2015 \\
\text { s/d Juni } 2016\end{array}$ & Terlapor menjabat sebagai Direktur PT. Bumi Madu Mandiri \\
\hline Kesimpulan & $\begin{array}{l}\text { Adanya jeda waktu Terlapor melakukan Rangkap Jabatan tanggal } 26 \\
\text { September } 2015 \text { s/d } 09 \text { November } 2015 \text { dan } 11 \text { Mei } 2016 \text { s/d } 24 \text { Juni } \\
2016\end{array}$ \\
\hline
\end{tabular}

Tabel 2. Alur rangkap jabatan yang dilakukan terlapor

Berdasarkan uraian pertimbanganpertimbangan tersebut penulis membuat dalam tabel mengenai alur rangkap jabatan yang dilakukan Terlapor. Dalam tabel tersebut dapat disimpulkan bahwa dalam pemeriksaan yang dilakukan Majelis Pemeriksa Pusat terdapat kesalahan karena berdasarkan pertimbangan alur rangkap jabatan yang dilakukan Terlapor ditemukan kesalahan. Kesalahan dimaksud adalah pada jeda waktu Terlapor dinyatakan mtaelakukan Rangkap Jabatan tanggal 26 September 2015 s/d 09 November 2015 padahal ditemukan bahwa Terlapor telah cuti pada tanggal 01 November 2014 s/d 31 Oktober 2015 yang artinya pada tanggal 26 September 2015 sebenarnya Terlapor telah cuti. Dengan adanya kesalahan perhitunggan tanggal ini menurut penulis pemeriksaan oleh MPP tidak rinci dan terkesan tidak melakukan pemeriksaan secara hati-hati. Pertimbangan dalam putusan MPD yang menyatakan Terlapor sebagai Majelis Kehormatan Notaris Wilayah Provinsi Lampung juga tidak menjadi pertimbangan pemberat bagi MPP dalam memberikan sanksi.

Sanksi yang diberikan oleh MPP dengan hanya Pemberhentian sementara selama 6 (enam) bulan dinilai tidak cukup untuk memberi efek jera dan menjadi contoh bagi Notaris lainnya. Sehingga penulis tidak sependapat dengan sanksi dalam Putusan yang dijatuhkan MPP karena dinilai kurang tegas. Pada dasarnya Notaris diangkat oleh pemerintah, bukan 
untuk kepentingan diri Notaris, tetapi untuk kepentingan masyarakat umum.

\section{E. PENUTUP}

\section{Kesimpulan}

1. Notaris dilarang melakukan rangkap jabatan sebagai pemimpin Badan Usaha Swasta menurut UUJN karena Notaris sebagai profesi yang bersifat mandiri, independent, tidak memihak salah satu pihak berbanding terbalik dengan profesi Pemimpin Badan Usaha Swasta yang tujuan utamanya adalah mencari keuntungan, sehingga apabila Notaris merangkap sebagai Pemimpin Badan Usaha Swasta maka akan terjadi benturan kepentingan (conflict interest).

2. Upaya MPN dalam menjalankan fungsi pengawasan terhadap pelanggaran rangkap jabatan yang dilakukan oleh Notaris adalah dengan melakukan pembinaan terhadap Notaris tentang pentingnya menjaga martabat Notaris selain itu MPP juga mengirimkan formulir cuti dan formulir pemeriksaan 1 (satu) kali dalam setahun sekali yang sifatnya berupa kebijakan dari MPP karena tidak di atur secara tegas dalam Undang-undang yang berfungsi untuk mengawasi Notaris dari kemungkinan melakukan rangkap jabatan.
3. Analisis terhadap Putusan Majelis Pemeriksa Pusat Notaris Nomor: 06/B/MPPN/X/2018 bahwa dengan adanya Putusan ini mengakibatkan penjatuhan sanksi pemberhentian sementara selama 6 bulan oleh Majelis Pengawas Pusat terhadap Notaris. Apabila memperhatikan Pasal yang diterapkan Majelis dalam memutus kasus pada dasarnya sudah sesuai aturan. Akan tetapi sanksi pemberhentian sementara yang hanya 6 bulan tersebut dirasa kurang tegas mengigat Notaris juga merupakan Wakil Ketua Majelis Kehormatan Notaris Wilayah Provinsi Lampung yang tindakannya dapat menjadi Notaris lain di Provinsi Lampung. Perbedaan pertimbanganpertimbangan Majelis di tingkat daerah, wilayah dan pusat dalam memutus kasus ini yang mengakibatkan perbedaan putusan menunjukkan kurangnya penyidikan dalam menangani kasus rangkap jabatan.

\section{Saran}

1. Dalam menjalankan jabatannya seharusnya seorang Notaris harus berpegang teguh pada sumpah jabatannya dan menjalankan jabatannya dengan berpedoman pada UUJN dan Kode Etik Notaris 
sehingga tindakan rangkap jabatan tidak akan terjadi lagi.

2. Perlu Penguatan struktur dan fungsi Majelis Pengawas di daerah, Wilayah dan Pusat, dengan adanya peningkatan anggaran Operasional sehingga anggota Majelis Pengawas memiliki kapasitas di dalam menjalankan fungsi dan tugasnya..

3. Perlu adanya sanksi yang lebih tegas dalam kasus rangkap jabatan karena akibat dari rangkap jabatan tentu saja sangat merugikan masyarakat terlebih lagi yang memiliki pengetahuan sedikit mengenai Hukum. Selain itu Pemerintah seharusnya memberikan perhatian lebih dalam pemberian anggaran bagi Majelis Pengawas Notaris (MPD, MPW dan MPP) yang dipergunakan untuk keperluan sarana dan prasarana kantor serta honor bagi anggota, sehingga kinerja dari Majelis Pengawas Notaris (MPD, MPW dan MPP) dapat lebih ditingkatkan serta mengadakan Sosialisasi Hukum tentang UUJN kepada masyarakat lua 


\section{A. Buku}

\section{DAFTAR PUSTAKA}

Ali, Zainuddin. Metode Penelitian Hukum. Raja Grafindo Persada. Jakarta. 1997.

Anshori, Abdul Ghofur. Lembaga Kenotariatan Indonesia Perspektif Hukum dan Etika. Jakarta. UII Press. 2009.

Bungin, Burhan. Analisis Data Penelitian Kualitatif. Pemahaman Filosofis Dan Metodologis Kearah Penguasaan Modal Aplikasi. Raja Grafindo Persada. Jakarta. 2004.

Effendi, Lutfi. Pokok-Pokok Huku Administrasi. Malang Bayumedia Publishing.2004.

Gandasubrata, H.R. Purwoto S. Renungan Hukum. Jakarta. IKAHI Cabang Mahkamah Agung RI. 1998.

Nasution, Bahder Johan. Metode Penelitian Ilmu Hukum. Mandar Maju. Bandung. 2008.

Prastowo, Andi. Memahami Metode-Metode Penelitian Suatu Tinjauan Teoritis dan Praktis. Ruzz Media. Yogyakarta. 2011.

Tim Penyusun Kamus Pusat Pembinaan dan Pengembangan Bahasa, Kamus Besar Bahasa Indonesia. Cetakan ke-3. Jakarta. Balai Pustaka. 1990.

\section{B. Peraturan Perundang-undangan}

Republik Indonesia, UU Nomor 2 Tahun 20014 tentang Perubahan Atas UU Nomor 30 Tahun 2004 Tentang Jabatan Notaris.

, Kitab Undang-undang Hukum Perdata

Peraturan Menteri Hukum dan Hak Asasi Manusia Nomor: M.02.PR.08.10 Tahun 2004 tentang Tata Cara Pengangkatan Anggota, Pemberhentian Anggota, Susunan Organisasi, Tata Kerja dan Tata Cara Pemeriksaan Majelis Pengawas Notaris.

25 Tahun 2014 Tentang Syarat dan Tata Cara Pengangkatan, Perpindahan, Pemberhentian dan Perpanjangan Masa Jabatan Notaris.

40 Tahun 2015 Tentang Susunan

Organisasi, Tata Cara Pengangkatan Anggota, Pemberhentian Anggota dan Tata Kerja Majelis Pengawas Notaris 
C. Jurnal dan Artikel

Budiono, Herlien. Notaris dan Kode Etiknya, Upgrading \& Refreshing Course Medan. Nasional Ikatan Notaris Indonesia. 30 Maret 2007.

D. KARYA ILMIAH

Napitupulu, Herlina Ernawti. Peran Ikatan Notaris Indonesia Dalam Pembinaan Notaris Dan Pengawasan Kode Etik Notaris di Wilayah Sumatera Utara. Tesis. Magister Kenotariatan Universitas Sumatera Utara. Medan. 2017. 